\title{
Jakość i dostępność opieki dla osób z zaburzeniami psychicznymi - opinie świadczeniodawców
}

\section{Quality and availability of care for people with mental disorders - assessment of health care providers}

\author{
Marta Bażydło, Beata Karakiewicz \\ Katedra i Zakład Zdrowia Publicznego Pomorskiego Uniwersytetu Medycznego w Szczecinie \\ ul. Żołnierska 48, 71-210 Szczecin \\ Kierownik: prof. dr hab. n. zdr. Beata Karakiewicz
}

\begin{abstract}
Introduction: The aim of this study was to identify the opinions of mental health care providers on the quality of their services. Materials and methods: The study was based on the opinions of mental health care providers. The study included facilities of the West Pomeranian province in Poland. A diagnostic survey was chosen as the research method. The questionnaire-based interview was carried out in facilities located in Szczecin. In other facilities the survey was carried out and the questionnaire was sent by post after prior calls. The study used a specially designed questionnaire which was based on quality categories proposed by Maxwell.

Results: In all categories of quality respondents most frequently indicated "high" and "average" scores. The "low" score was rarely reported. The best rated category of quality is justice in access to services. As many as $93.3 \%$ of respondents gave the highest rating to this category, and $6.7 \%$ rated it as average. The second
\end{abstract}

\section{STRESZCZENIE}

Wstęp: Celem pracy było poznanie opinii świadczeniodawców opieki psychiatrycznej na temat jakości udzielanych usług.

Materiał i metody: Materiał stanowiły opinie przedstawicieli placówek opieki psychiatrycznej na temat jakości udzielanych usług. Do badania włączono placówki z województwa zachodniopomorskiego. Wybraną metodą badawczą był sondaż diagnostyczny. W placówkach znajdujących się na terenie Szczecina przeprowadzono wywiad wspierany kwestionariuszem ankiety. W pozostałych placówkach przeprowadzono ankietę, a kwestionariusz wysłano pocztą po uprzedniej rozmowie telefonicznej. W badaniu posłużono się autorskim kwestionariuszem, który został skonstruowany w oparciu o kategorie jakości wyróżnione przez Maxwella.

Wyniki: We wszystkich kategoriach jakości najczęściej wskazywane oceny to odpowiedź „wysoka” i „średnia”. Odpowiedź „niska” była wskazywana niezwykle rzadko. Najwyżej oceniona kategoria jakości to sprawiedliwość w dostępie do usług. Aż 93,3\% pytanych przyznało tej kategorii najwyższą ocenę, best assessed category was the competence of personnel. As many as $80.0 \%$ of respondents representing health care centres rated personnel competence as high. The third top-rated category of quality was the effectiveness of services, or the provision of services in accordance with current knowledge and current scientific reports. As many as $76.7 \%$ of respondents rated the effectiveness of their services as high. The lowest rated category of quality was the adaptation of buildings to the needs of patients, and the safety of procedures.

Conclusions: 1 . Representatives of psychiatric care facilities highly rated the quality of services provided by their facility. 2. Top-rated quality categories were justice in access to services, personnel competence, and efficiency of the services. 3 . The lowest rated categories were the adaptation of facilities to the needs of patients, and the safety of procedures.

Keywords: health services availability, mental health services, quality of health care. a 6,7\% oceniło jej poziom jako średni. Druga najlepiej oceniona kategoria to kompetencje personelu. Aż 80,0\% przedstawicieli placówek oceniło kompetencje personelu jako wysokie. Trzecia spośród najwyżej ocenionych kategorii jakości to skuteczność usług, czyli świadczenie usług zgodnie z aktualnymi wymaganiami wiedzy i aktualnymi doniesieniami nauki. Aż 76,7\% pytanych oceniło skuteczność podejmowanych przez siebie świadczeń jako wysoką. Z kolei najniżej ocenione kategorie jakości to dostosowanie budynku do potrzeb pacjentów oraz bezpieczeństwo procedur.

Wnioski: 1. Przedstawiciele placówek opieki psychiatrycznej wysoko oceniają jakość usług świadczonych przez reprezentowane przez siebie placówki. 2. Najwyżej oceniane kategorie jakości to sprawiedliwość w dostępie do usług, kompetencje personelu oraz skuteczność usług. 3. Najniżej oceniane kategorie jakości to dostosowanie budynku do potrzeb pacjentów oraz bezpieczeństwo procedur.

Słowa kluczowe: dostępność opieki zdrowotnej, opieka psychiatryczna, jakość opieki zdrowotnej.

\section{WSTĘP}

Odpowiedzią na wzrost liczby osób korzystających z usług opieki psychiatrycznej oraz zalecenia Światowej Organizacji
Zdrowia (polegające na rozwijaniu opieki środowiskowej) miały być Narodowy Program Ochrony Zdrowia Psychicznego na lata 2011-2015 oraz Regionalny Program Ochrony Zdrowia Psychicznego dla województwa zachodniopomorskiego na lata 
2011-2015. Celem obu tych programów było zapewnienie osobom z zaburzeniami psychicznymi wielostronnej i powszechnie dostępnej opieki [1, 2]. W piśmiennictwie wskazuje się, że dostępność usług jest jednym z komponentów jakości. 0 ile nie istnieje jedna powszechnie obowiązująca definicja jakości, o tyle badacze są zgodni co do jej wielostronnego charakteru.

Za twórcę pojęcia „jakość” uważa się Platona. Uznał on ją za stopień doskonałości, uważał bowiem, że rzeczywistości nie da się opisać tylko poprzez kryteria ilościowe $[3,4,5]$. Niestety, kompleksowe wdrażanie działań zapewniających jak najwyższą jakość w opiece nad pacjentem nastąpiło dopiero w XX w. Wtedy zaczęto postrzegać jakość jako zgodność z wymaganiami (twórcą takiego podejścia był P.B. Crosby). Inni badacze, definiując jakość, wzięli pod uwagę fakt, że osiągnięcie najwyższego poziomu jakości jest ograniczane przez wiele czynników. I tak W. Deming określił jakość jako przewidywalny stopień różnorodności i niezawodności przy możliwie niskich kosztach i dopasowaniu do wymagań rynku [3, 4, 6]. Maxwell wśród elementów jakości, obok dostępności, wymienia sprawiedliwość, skuteczność, adekwatność, akceptację społeczną, wydajność, kompetencje personelu, bezpieczeństwo procedur, satysfakcję pacjentów, wyposażenie placówki oraz dostosowanie budynku do potrzeb pacjentów [5, 7].

Jakość udzielanych usług powinna mieć zasadnicze znaczenie nie tylko dla kreatorów polityki zdrowotnej tworzących takie programy jak Narodowy Program Ochrony Zdrowia Psychicznego czy też regionalne programy ochrony zdrowia psychicznego dla poszczególnych województw. Powinna być ona priorytetem także dla osób zarządzających podmiotami leczniczymi, jak i dla osób bezpośrednio świadczących usługi zdrowotne [3].

Znaczenie jakości podkreśla fakt, że zgodnie z literaturą przedmiotu wyniki leczenia pacjentów cierpiących na te same dolegliwości różnią się w poszczególnych regionach i szpitalach, nawet przy identycznym finansowaniu, zaopatrzeniu w sprzęt oraz takich samych zasobach kadrowych [4]. Jakość opieki zdrowotnej nabiera szczególnego znaczenia w kontekście opieki psychiatrycznej. Pacjent cierpiący na zaburzenia psychiczne jest narażony na stygmatyzację i brak wsparcia rodziny. W związku z powyższym zadaniem podmiotów leczniczych jest zapewnienie na tyle wysokiego poziomu usług, by sprawowana opieka pełniła, poza efektem leczniczym, rolę umacniającą dla chorego [5].

Problem jakości w ochronie zdrowia jest poruszany w związku z następującymi jej aspektami: kontrolą, oceną, poprawą, zapewnieniem jakości i zarządzaniem nią [3]. Ocena jakości, która stanowi przedmiot przeprowadzonych badań, dotyczy poznania realnego poziomu świadczenia usług. Tego typu oceny polegają zazwyczaj na zbadaniu satysfakcji pacjenta [3]. Chcąc poznać całościowo jakość usług opieki psychiatrycznej w województwie zachodniopomorskim, zbadano jakość z dwóch perspektyw. W pierwszej kolejności pod uwagę wzięto opinie na temat jakości świadczonych usług wśród przedstawicieli opieki psychiatrycznej, a w następnym etapie zostanie przeprowadzony sondaż diagnostyczny wśród pacjentów.
Celem pracy było poznanie opinii świadczeniodawców opieki psychiatrycznej na temat jakości udzielanych usług.

\section{MATERIA I METODY}

Materiał stanowiły opinie przedstawicieli placówek opieki psychiatrycznej na temat jakości udzielanych usług. Do badania włączono wszystkie podmioty udzielające świadczenia opieki psychiatrycznej w województwie zachodniopomorskim na podstawie kontraktu z Narodowym Funduszem Zdrowia (NFZ). Do badania przystąpiło 30 (38,5\%) spośród 78 placówek świadczących opiekę psychiatryczną w regionie.

Wybraną metodą badawczą był sondaż diagnostyczny. W placówkach znajdujących się na terenie Szczecina przeprowadzono wywiad wspierany kwestionariuszem ankiety, natomiast w pozostałych ankietę. Kwestionariusz wysłano pocztą, po uprzedniej rozmowie telefonicznej.

W badaniu posłużono się autorskim kwestionariuszem, który został skonstruowany w oparciu o kategorie jakości wyróżnione przez Maxwella. Respondentów poproszono o ocenę każdej z tych kategorii, wśród których znalazły się: dostępność, sprawiedliwość, skuteczność, adekwatność, akceptacja społeczna, wydajność, kompetencje personelu, bezpieczeństwo procedur, satysfakcja pacjentów, wyposażenie placówki, dostosowanie budynku do potrzeb pacjentów. Respondentów poproszono o wskazanie jednej z następujących odpowiedzi: wysoka, średnia, niska, trudno ocenić.

Ze względu na niedużą liczbę respondentów uzyskanych wyników nie poddano analizie statystycznej.

\section{WYNIKI}

Wyniki badań przedstawiono w tabeli 1. W pierwszej kolejności należy zauważyć, że najczęściej wskazywane oceny we

TABELA 1. Oceny poszczególnych kategorii jakości

\begin{tabular}{lcccc}
\multicolumn{1}{c}{ Kategoria jakości } & $\begin{array}{c}\text { Wysoka } \\
(\%)\end{array}$ & $\begin{array}{c}\text { Średnia } \\
(\%)\end{array}$ & $\begin{array}{c}\text { Niska } \\
(\%)\end{array}$ & $\begin{array}{c}\text { Brak } \\
\text { zdania } \\
(\%)\end{array}$ \\
\hline Dostępność & 60,0 & 36,7 & 0 & 3,3 \\
\hline Sprawiedliwość & 93,3 & 6,7 & 0 & 0 \\
\hline Skuteczność & 76,7 & 10,0 & 0 & 13,3 \\
\hline $\begin{array}{l}\text { Adekwatność usług } \\
\text { do potrzeb pacjentów }\end{array}$ & 66,7 & 30,0 & 0 & 3,3 \\
\hline Akceptacja społeczna & 53,3 & 40,0 & 0 & 6,7 \\
\hline Wydajność & 46,7 & 36,7 & 3,3 & 13,3 \\
\hline Kompetencje personelu & 80,0 & 10,0 & 0 & 10,0 \\
\hline Bezpieczeństwo procedur & 56,7 & 26,7 & 6,6 & 10,0 \\
\hline Satysfakcja pacjentów & 40,0 & 16,7 & 0 & 43,3 \\
\hline Wyposażenie placówki & 36,7 & 40,0 & 0 & 23,3 \\
\hline $\begin{array}{l}\text { Dostosowanie budynku } \\
\text { do potrzeb pacjentów }\end{array}$ & 46,7 & 30,0 & 10,0 & 13,3 \\
\hline \begin{tabular}{l} 
Jakość \\
\hline
\end{tabular} & 66,7 & 13,3 & 0 & 20,0 \\
\hline
\end{tabular}


wszystkich kategoriach to odpowiedź „wysoka” $\mathrm{i}$ „,́rednia”. Odpowiedź „niska” była wskazywana niezwykle rzadko.

\section{Najwyżej ocenione kategorie jakości}

Najwyżej oceniona kategoria jakości to sprawiedliwość w dostępie do usług. Oznacza ona równy dostęp do usług, bez względu na wiek, płeć, miejsce zamieszkania czy też inne nieuzasadnione czynniki. Aż 93,3\% pytanych przyznało tej kategorii najwyższą ocenę, a 6,7\% oceniło jej poziom jako średni. Pozostałe możliwe warianty odpowiedzi nie zostały wskazane.

Druga najlepiej oceniona kategoria jakości to kompetencje personelu. Aż 80,0\% przedstawicieli placówek oceniło kompetencje personelu jako wysokie. Kompetencje te zostały ocenione jako średnie przez 13,3\% respondentów, a co dziesiąty pytany nie miał zdania w tej kwestii.

Trzecia spośród najwyżej ocenionych kategorii jakości to skuteczność usług, czyli świadczenie usług zgodnie z aktualnymi wymaganiami wiedzy i aktualnymi doniesieniami nauki. Aż 76,7\% pytanych oceniło skuteczność podejmowanych przez siebie świadczeń jako wysoką. Co dziesiąty pytany ocenił tę kategorię jako średnią. W żadnej placówce nie została ona oceniona jako niska, a 13,3\% pytanych nie miało zdania w tej kwestii.

\section{Najniżej ocenione kategorie jakości}

Z kolei najniżej ocenione kategorie jakości to dostosowanie budynku do potrzeb pacjentów oraz bezpieczeństwo procedur. W co dziesiątej placówce dostosowanie budynku do potrzeb pacjentów zostało ocenione jako niskie. Jednocześnie 46,7\% respondentów oceniło to dostosowanie jako wysokie, a 30\% jako średnie. Bezpieczeństwo wykonywanych procedur to unikanie niepożądanych zdarzeń mogących wystąpić w trakcie leczenia. Bezpieczeństwo za niskie uznało 6,7\% pytanych. Kategoria ta została oceniona jako wysoka przez $56,7 \%$ ankietowanych, a jako średnia przez $26,7 \%$ pytanych.

Bardzo ważnym wyznacznikiem jakości jest satysfakcja pacjentów. Jednakże jej badanie nie jest powszechne. Badanie satysfakcji pacjentów zdeklarowała co piąta placówka, której przedstawiciele oceniali zadowolenie podopiecznych na podstawie rozmów z nimi. I tak $40 \%$ respondentów oceniło satysfakcję pacjentów jako wysoką, a 16,7\% jako średnią. Pozostali pytani nie mieli zdania na ten temat.

W jednym z pytań zapytano ankietowanych, jak generalnie oceniają jakość usług świadczonych przez reprezentowaną przez siebie placówkę. 66,67\% respondentów oceniło ją jako wysoką, a 13,3\% jako średnią. Żadna osoba nie oceniła jakości usług jako niskiej, a co piąty pytany nie miał zdania w tej kwestii.

Zapytano także, czy w reprezentowanej placówce istnieje program poprawy jakości. Pozytywną odpowiedź udzieliło $22,6 \%$ osób, a negatywną - 77,4\%.

W kontekście realizacji założeń Narodowego Programu Ochrony Zdrowia Psychicznego na szczególną uwagę zasługuje ocena dostępności usług opieki psychiatrycznej. Dostępność oznacza osiągalność usług w odpowiednim czasie. W przeprowadzonych badaniach $60 \%$ pytanych uznało dostępność do świadczeń placówki za wysoką, a 36,7\% za średnią. Pozostałe osoby nie miały zdania w tej kwestii.

\section{Ocena dostępności w placówkach świadczących opiekę otwartą i zamkniętą}

Wśród badanych placówek 24 (80\%) świadczyły opiekę otwartą. Znajdowały się wśród nich poradnie zdrowia psychicznego, w tym dla dzieci i młodzieży, poradnie terapii uzależnienia od alkoholu i substancji psychoaktywnych, poradnie psychologiczne, zespoły leczenia środowiskowego, a także oddziały dzienne psychiatryczne i leczenia uzależnienia od alkoholu. Z kolei 6 (20\%) placówek świadczyło opiekę zamknięta. W przypadku 4 placówek świadczenia całodobowe były połączone z działalnością opieki otwartej.

W tabelach 2 i 3 przedstawiono porównanie oceny dostępności i jakości usług w placówkach otwartych i zamkniętych.

TABELA 2. Ocena dostępności w placówkach otwartych i zamkniętych

\begin{tabular}{lcc} 
Dostępność & $\begin{array}{c}\text { Opieka otwarta } \\
(\%)\end{array}$ & $\begin{array}{c}\text { Opieka zamknięta } \\
(\%)\end{array}$ \\
\hline Wysoka & 54,1 & 83,3 \\
\hline Średnia & 41,7 & 16,7 \\
\hline Niska & 0 & 0 \\
\hline Trudno ocenić & 4,2 & 0 \\
\hline
\end{tabular}

TABELA 3. Ocena jakości w placówkach otwartych i zamkniętych

\begin{tabular}{lcc} 
Jakość & $\begin{array}{c}\text { Opieka otwarta } \\
(\%)\end{array}$ & $\begin{array}{c}\text { Opieka zamknięta } \\
(\%)\end{array}$ \\
\hline Wysoka & 62,5 & 83,3 \\
\hline Średnia & 16,7 & 0 \\
\hline Niska & 0 & 0 \\
\hline Trudno ocenić & 20,8 & 16,7
\end{tabular}

Przedstawiciele opieki zamkniętej lepiej ocenili dostępność do reprezentowanych przez siebie placówek niż przedstawiciele opieki otwartej. Aż 83,3\% osób z placówek opieki zamkniętej uznało dostępność do reprezentowanej przez siebie placówki jako wysoką. W przypadku opieki zamkniętej było to $54,1 \%$.

Również jakość udzielanych usług lepiej ocenili przedstawiciele opieki zamkniętej. Jako wysoką uznało ją 83,3\% przedstawicieli tej formy opieki, a w przypadku opieki otwartej było to $62,50 \%$ respondentów.

\section{Ocena dostępności a miejsce położenia placówki}

W kolejnym etapie dokonano porównania oceny dostępności usług w zależności od tego, czy placówka znajduje się w dużym mieście, jakim jest Szczecin, czy też poza nim. Wśród placówek biorących udział w badaniu $14(46,7 \%)$ znajdowało się na terenie Szczecina, a 16 (53,3\%) poza nim.

$\mathrm{Z}$ danych przedstawionych w tabeli 4 wynika, że $64,3 \%$ przedstawicieli placówek położonych w Szczecinie oceniło dostępność usług jako wysoką, a w przypadku placówek położonych poza Szczecinem odsetek ten był mniejszy i wynosił $56,3 \%$. 
TABELA 4. Ocena dostępności placówki a miejsce jej położenia

\begin{tabular}{lcc} 
Dostępność & $\begin{array}{c}\text { Placówki położone } \\
\text { w Szczecinie } \\
\text { (\%) }\end{array}$ & $\begin{array}{c}\text { Placówki położone } \\
\text { poza Szczecinem } \\
\text { (\%) }\end{array}$ \\
\hline Wysoka & 64,3 & 56,3 \\
\hline Średnia & 35,7 & 37,4 \\
\hline Niska & 0 & 0 \\
\hline Trudno ocenić & 0 & 6,3 \\
\hline
\end{tabular}

\section{Ocena dostępności a czas oczekiwania na możliwość skorzystania z usług placówki}

Ankietowani zostali poproszeni o podanie czasu oczekiwania pacjenta na możliwość skorzystania z usług placówki. Oddzielnie zapytano o czas oczekiwania na opiekę otwartą i zamkniętą. Następnie porównano czas oczekiwania z oceną dostępności.

\section{Opieka zamknięta}

W tabeli 5 przedstawiono porównanie czasu oczekiwania na miejsce w placówce zamkniętej i oceny dostępności. Na podstawie wyników nie można stwierdzić, że im krótszy okres oczekiwania na miejsce w placówce zamkniętej, tym lepsza ocena dostępności. Należy zauważyć, że spośród 4 placówek, w których czas oczekiwania był najdłuższy i wynosił ponad 2 miesiące, aż 3 respondentów oceniło dostępność placówki jako wysoką.

TABELA 5. Czas oczekiwania na miejsce w placówce zamkniętej a ocena dostępności

\begin{tabular}{lccccc}
\multicolumn{1}{c}{$\begin{array}{c}\text { Czas } \\
\text { oczekiwania }\end{array}$} & \multicolumn{3}{c}{$\begin{array}{c}\text { Ocena dostępności } \\
\text { (liczba wskazań odpowiedzi) }\end{array}$} & Suma \\
\cline { 2 - 5 } & wysoka & średnia & niska & $\begin{array}{c}\text { brak } \\
\text { zdania }\end{array}$ & \\
\hline $\begin{array}{l}\text { Do 1 tygodnia } \\
\text { włącznie }\end{array}$ & 2 & 0 & 0 & 0 & 2 \\
\hline $\begin{array}{l}\text { Ponad 1 tydzień } \\
\text { do 1 miesiąca }\end{array}$ & 0 & 1 & 0 & 0 & 1 \\
\hline $\begin{array}{l}\text { Ponad 1 miesiąc } \\
\text { do 2 miesięcy }\end{array}$ & 0 & 0 & 0 & 0 & 0 \\
\hline \begin{tabular}{l} 
Ponad 2 miesiące \\
\hline
\end{tabular} & 3 & 1 & 0 & 0 & 4 \\
\hline
\end{tabular}

\section{Opieka otwarta}

W przypadku opieki otwartej brano pod uwagę czas oczekiwania na miejsce na oddziale dziennym lub na pierwszą wizytą $\mathrm{w}$ poradni. Zgodnie z danymi zawartymi w tabeli 6 można

TABELA 6. Czas oczekiwania na usługi placówki otwartej a ocena dostępności

\begin{tabular}{lccccc} 
& \multicolumn{1}{c}{$\begin{array}{c}\text { Ocena dostępności } \\
\text { Cczekiwania }\end{array}$} & \multicolumn{2}{c}{ (liczba wskazań odpowiedzi) } & Suma \\
\cline { 2 - 5 } & wysoka & średnia & niska & $\begin{array}{c}\text { brak } \\
\text { zdania }\end{array}$ & \\
\hline $\begin{array}{l}\text { Do 1 tygodnia } \\
\text { włącznie }\end{array}$ & 11 & 4 & 0 & 0 & 15 \\
\hline $\begin{array}{l}\text { Ponad 1 tydzień } \\
\text { do 1 miesiąca }\end{array}$ & 2 & 1 & 0 & 0 & 3 \\
\hline $\begin{array}{l}\text { Ponad 1 miesiąc } \\
\text { do 2 miesięcy }\end{array}$ & 2 & 2 & 0 & 0 & 3 \\
\hline Ponad 2 miesiące & 0 & 2 & 0 & 1 & 3 \\
\hline
\end{tabular}

zaobserwować, że w opiece otwartej im dłuższy czas oczekiwania pacjenta, tym przedstawiciele placówek gorzej oceniali dostępność do swojej placówki. Wśród placówek, w których czas oczekiwania nie przekraczał 1 miesiąca, wyraźnie częściej oceniano dostępność jako wysoką niż w innych placówkach.

\section{DYSKUSJA}

Przedstawione wyniki doprowadziły do postawienia bardzo ważnego pytania: czy tak dobra ocena jakości wynika z braku krytycyzmu przedstawicieli placówek, czy też z faktycznie wysokiego poziomu udzielania świadczeń w opiece psychiatrycznej? Pewną odpowiedzią na to pytanie będzie kolejny etap badań, w którym o podzielenie się swoją opinią zostaną poproszeni pacjenci. Tymczasem można odnieść uzyskane wyniki do wyników badań innych autorów.

Podczas badań Anczewskiej i wsp. poproszono pacjentów psychiatrycznych oddziałów całodobowych o udzielenie odpowiedzi na dwa pytania otwarte: co najbardziej i co najmniej podobało się podczas hospitalizacji. Większość opinii (748) było pozytywnych, a mniejsza część (370) odpowiedzi była negatywna. Pacjenci zwracali uwagę na przyjazną postawę personelu, przejawiali uznanie wobec socjoterapii i psychoterapii, a także zwracali uwagę na dobre warunki pobytu (wygląd oddziału, otoczenie). Odpowiedzi negatywne dotyczyły ograniczenia swobody, zatłoczenia oddziałów, niedoboru informacji na temat leczenia oraz prowadzonych zajęć [8]. Zgodnie z wynikami innych badań tego zespołu, zdecydowana większość pacjentów (ponad 95\%) była zadowolona z kontaktu z personelem. Niepokojące są jednak odpowiedzi dotyczące wsparcia udzielanego przez personel. Otrzymanie wsparcia od lekarza zdeklarowało $44,9 \%$ pacjentów, od pielęgniarki 51,6\%, a od psychologa 20,6\% pytanych. Dobrze natomiast zostały ocenione warunki panujące na oddziale (czystość, wyposażenie sal, jakość posiłków) [9]. Zgodnie z wynikami innych badań przeprowadzonych wśród pacjentów oddziałów psychiatrycznych poprawy wymagają aktywność psychologów i terapeutów zajęciowych, dostęp do informacji formalnych i medycznych oraz warunki pobytu związane z infrastrukturą oddziału [10]. W badaniach Zarzecznej-Baran i wsp., również przeprowadzanych wśród pacjentów psychiatrycznych oddziałów całodobowych, większość pytanych pozytywnie oceniło udzielaną opiekę. Pozytywna ocena dotyczyła zarówno warunków, relacji z personelem, jak i pozytywnego wpływu pobytu na oddziale na poprawę stanu zdrowia. Natomiast niekorzystnie oceniony został przekaz informacji na temat stanu zdrowia, sposobów leczenia i ryzyka związanego z leczeniem. Duży odsetek pacjentów nie został zapoznany z Kartą Praw Pacjenta i z regulaminem oddziału [11].

Również środowiskowa opieka psychiatryczna została dobrze oceniona przez pacjentów. W badaniach Prot i wsp. ogólne zadowolenie z opieki zdeklarowało 78,8\% pytanych. Najniżej zostały ocenione kwestie udzielania informacji na temat diagnozy, metod leczenia, o ofercie i programach ośrodka [12].

Z przytoczonych wyników można wyciągnąć wniosek, że ogólnie jakość opieki psychiatrycznej jest wysoko oceniana 
przez pacjentów, jednakże istnieją jej aspekty, które należy poprawić. Kwestie te dotyczą przede wszystkim udzielania pacjentom informacji na temat diagnozy, metod leczenia, zasad panujących na oddziale.

Niepokojący jest fakt, że zgodnie z wynikami badań własnych w zdecydowanej większości placówek nie funkcjonuje program poprawy jakości. Zgodnie z koncepcją zarządzania jakością, jakość można poprawić jedynie poprzez systematyczne działania przy współpracy całego personelu [2]. Trudno mówić o poprawie jakości, jeśli brak jest zarządzania nią, a przedstawiciele placówek nie dostrzegają pól do jej poprawy. Może to wynikać z braku przeprowadzania badań satysfakcji pacjentów. Informacje zwrotne od osób hospitalizowanych mogłyby stanowić wyznacznik dla kadr zarządzających, co należy poprawić, a co jest przez pacjentów pozytywnie postrzegane.

Biardzki problemy funkcjonowania opieki psychiatrycznej nazywa „enklawą wstydu”. Postrzega on psychiatrię jako miejsce zapomniane i strukturalnie niedofinansowane [13]. Kolejny argument mówiący o tym, że sytuacja opieki psychiatrycznej nie jest tak dobra, jak postrzegają ją respondenci, jest fakt wprowadzenia Narodowego Programu Ochrony Zdrowia Psychicznego. Jest on postrzegany jako program bardzo dobry, przełomowy, dostosowujący organizację polskiej psychiatrii do założeń Światowej Organizacji Zdrowia. Jednakże program ten nie jest realizowany $[13,14]$. Jako przyczyny braku realizacji programu wskazuje się brak finansowania i wewnętrzną niespójność przepisów.

Ta negatywna opinia na temat funkcjonowania psychiatrii w Polsce nie przekłada się na ocenę jakości świadczeniodawców co do usług udzielanych przez reprezentowaną przez siebie placówkę. I być może jest to jedna z barier wdrażania nowych rozwiązań organizacyjnych. Jeśli świadczeniodawcy opieki psychiatrycznej i menadżerowie podmiotów leczniczych nie uważają, że którakolwiek z kategorii jakości w ich podmiotach wymaga zmian, to zmiany te z pewnością nie będą wdrażane. Z drugiej strony być może zmiany, które należy wdrożyć, nie zależą od pojedynczych placówek, ale mają charakter bardziej ogólny, jak np. zmiany w prawodawstwie czy działalności NFZ. Aby się tego dowiedzieć, w kolejnym etapie badań powołane zostanie interdyscyplinarne gremium doradcze. Będzie się ono składało z lekarzy psychiatrów, pielęgniarek psychiatrycznych, psychologów, przedstawicieli opieki społecznej, kreatorów lokalnej polityki, a także prawników. Celem spotkań gremium będzie wskazanie, jakie są obecne problemy organizacyjne psychiatrii i jak należy je rozwiązać. Ponadto niniejsze badania będą uzupełnione sondażem diagnostycznym na temat jakości otrzymywanych usług wśród pacjentów opieki psychiatrycznej.

Należy zwrócić uwagę na mający miejsce w ostatnich latach wzrost liczby pacjentów korzystających z opieki psychiatrycznej. Według opinii niektórych autorów jest to skutek transformacji ustrojowej. W województwie zachodniopomorskim utrzymuje się jedna z najwyższych stóp bezrobocia w Polsce, obecnie na poziomie $16,4 \%$. Jest to jedno z zagrożeń zdrowia psychicznego mieszkańców regionu. Jednocześnie aż 45\% Polaków niepokoi się o swoje zdrowie psychiczne. Są to sygnały, że zmiany organizacyjne w opiece psychiatrycznej są nieuniknione $[2,15,16,17]$. Powinny im towarzyszyć działania na rzecz podniesienia jakości usług.

\section{WNIOSKI}

1. Przedstawiciele placówek opieki psychiatrycznej wysoko oceniają jakość usług świadczonych przez reprezentowane przez siebie placówki.

2. Najwyżej oceniane kategorie jakości to sprawiedliwość w dostępie do usług, kompetencje personelu oraz skuteczność usług.

3. Najniżej oceniane kategorie jakości to dostosowanie budynku do potrzeb pacjentów oraz bezpieczeństwo procedur.

4. Większość placówek opieki psychiatrycznej nie ma programu poprawy jakości ani nie bada satysfakcji pacjentów z otrzymywanych usług.

5. Przedstawiciele opieki zamkniętej lepiej ocenili dostępność do reprezentowanych przez siebie placówek niż przedstawiciele opieki otwartej.

6. Przedstawiciele opieki zamkniętej lepiej ocenili jakość świadczonych usług niż przedstawiciele opieki otwartej.

7. Przedstawiciele placówek położonych w Szczecinie lepiej ocenili dostępność do oferowanych przez siebie usług niż przedstawiciele placówek położonych poza Szczecinem.

8. W placówkach opieki otwartej im dłuższy czas oczekiwania pacjenta na możliwość skorzystania z usług placówki, tym przedstawiciele placówek gorzej oceniali dostępność do placówki. Natomiast w placówkach opieki zamkniętej ocena dostępności nie zależy od czasu oczekiwania pacjenta na możliwość skorzystania z usług.

\section{PIŚMIENNICTWO}

1. Narodowy Program Zdrowia na lata 2007-2015. Załącznik do Uchwały nr 90/2007 Rady Ministrów z dnia 15 maja 2007 r. http://www2.mz.gov. pl/wwwfiles/ma_struktura/docs/zal_urm_npz_90_15052007p.pdf (24.07.2014).

2. Regionalny Program Ochrony Zdrowia Psychicznego dla Województwa Zachodniopomorskiego na lata 2011-2015. Szczecin: Urząd Marszałkowski Województwa Zachodniopomorskiego; 2011. http://www.wzp. pl/uploads/pliki/RPOZP_2011-2015.pdf (24.07.2014).

3. Staszewski R, Kautsch M. Jakość w ochronie zdrowia. In: Kautsch M, editor. Zarządzanie w opiece zdrowotnej. Nowe wyzwania. Warszawa: Wolters Kluwer; 2010. p. 311-35.

4. Staszewski R, Głowacka MD. Pojęcie jakości. Od teorii do praktyki. In: Głowacka MD, editor. Zarządzanie zakładem opieki zdrowotnej. Wybrane konteksty teoretyczno-praktyczne. Poznań: Termedia; 2004. p. 75-88.

5. Indulska A, Anczewska M, Raduj J, Prot K, Pałyska M. Ocena jakości usług medycznych w psychiatrycznej opiece zdrowotnej. Warszawa: Instytut Psychiatrii i Neurologii; 2008.

6. Kindalski E, Bagiński J. Podstawy zarządzania przez jakość. Q Team; 1997.

7. Piątek A. Zarządzanie jakością. In: Ksykiewicz-Dorota A, editor. Zarządzanie w pielęgniarstwie. Podręcznik dla studentów studiów magisterskich Wydziałów Pielęgniarstwa oraz Wydziałów Nauk o Zdrowiu. Lublin: Czelej; 2005. p. 303-24.

8. Anczewska M, Indulska A, Raduj J, Pałyska M, Prot K. The patients' view on psychiatric hospitalization - a qualitative evaluation. Psychiatr Pol 2007;41(3):427-34 
9. Anczewska M, Raduj J, Indulska A, Pałyska M, Prot K. Porównanie opinii pacjentów o jakości opieki na oddziałach psychiatrycznych i neurologicznych. Psychiatr Pol 2010;44(2):255-65.

10. Raduj J, Indulska A, Anczewska M, Lechowicz W, Pałyska M, Prot K. Quality of inpatient psychiatric services as rated by patients of selected psychiatric wards. Post Psychiat Neurol 2005;14(4):293-98.

11. Zarzeczna-Baran M, Bandurska E, Nowalińska M, Daniluk R. Ocena jakości usług opiekuńczo-leczniczych dokonana przez pacjentów psychiatrycznego lecznictwa zamkniętego. Ann Acad Med Gedan 2012;42:41-52.

12. Prot K, Pałyska M, Anczewska M, Indulska A, Raduj J. Patient satisfaction with community-based psychiatric care. Post Psychiat Neurol 2005;14(4):299-304

13. Biardzki M. Enklawy wstydu. Służ Zdr 2012;69(76):8-12.
14. Kiejna A, Ciałkowska-Kuźmińska M, Piotrowski P. Narodowy Program Ochrony Zdrowia Psychicznego - idea czy rzeczy wistość? Psychiatr Pol 2012;46(3):499-502.

15. Herczyńska G, Czabała C, Namysłowska I. Podjąć wyzwania, szukać rozwiązań - zdrowie psychiczne w centrum uwagi rządów państw europejskich. Post Psychiat Neurol 2005;14(3):259-66.

16. Wciórka B, Wciórka J. Sondaż opinii publicznej - czy Polacy niepokoją się o swoje zdrowie psychiczne? Post Psychiat Neurol 2005;14(4):305-17.

17. Miesięczna informacja o bezrobociu rejestrowanym $w$ Polsce $w$ maju 2014 r. Główny Urząd Statystyczny. http://stat.gov.pl/obszary-tematyczne/ praca-wynagrodzenia/bezrobocie-stopa-bezrobocia/miesieczna-informacja-o-bezrobociu-rejestrowanym-w-polsce-w-maju-2014-roku,1,28.html\# (24.07.2014). 